\title{
Cripps Mission: the Beginning Process to the way of Indian Independence
}

\author{
Sukanta Pramanik, \\ PhD Research Scholar, Department of History, Visva-Bharati, Santiniketan, pin-731235, District-Birbhum, \\ West Bengal, India.
}

\begin{abstract}
The March, 1942 is marked with the event of Cripps Mission in India. Sending by the British war cabinet, the main purpose of this Mission was to gain India's political and military support. Because during the early period of Second World War, Britain was too much disturbed by the victories of Axis powers and the joining of Japan in Axis groups. In this crucial situation the possibility of the Japanese attack on India was raised. That's why Cripps Mission was launched. But its main offer i.e. the Dominion Status after the war and not a single word mention for war time National Government Compelled the Indian leaders to reject the Cripps proposals. But it is not the whole story. It must be said that with the Cripps Mission the process of constitutional development in India acquired a new dimension. At the same time the desperateness of Indian leaders due to Cripps's failure compelled them to launch more intense mass movement which accelerated the process of gaining the independence for India. Thus it can be said that Cripps Mission is the beginning process to the way of Indian independence.
\end{abstract}

Keywords: British war cabinet, Cripps Mission, Dominion Status, Gandhi's attitude, Quit India Movement, Constitutional concessions.

\section{Introduction}

The time of mid-March in 1942 is a very significant phase in the history of colonial India. As Great Britain gradually lost their ground in the beginning of Second World War, its position became very critical in international politics and military also. After the joining of Japan in favour of Axis powers in the said war and its tremendous success, the immediate realisation of Great Britain was that it needs the support of India in the aspects of economy, military and politics. In order to gain the Indian support, Britain now felt the necessity to start some discussion on the constitutional future of India. This necessity had set the British in making the decision to send the Cripps Mission in India. However, the proposal of the mission under the leadership of sir Stafford Cripps was the dominion status centric. Moreover there was not so immediate promise for India. So according to natural expectation, the leaders of almost all the political parties in India rejected the Cripps proposal. Thus the mission was failed.

But it is not the all. It must be said that the Cripps Mission had started the process to the way of Indian independence. In this aspect the mission had brought two important changes in both the attitude of Great Britain and Indian leaders. First, though the proposals of the mission did not satisfied the Indian leaders according to their expected demands but its promises like post war dominion status with the right of secession, a 'constitution making body' elected by provincial legislatures, with individual provinces being given the right not to join it and the states being invited to appoint representatives-all these significant issues had made clear one thing that gradually Britain was taking the preparation to lose the stronghold on India. At least through the efforts of Cripps Mission, it can be say that Indian independence was a near and not a remote reality[1]. Though there is one common debate among the historians that whether only by talking about the post war dominion status, the British authority intended to put the ideas of Indian freedom into cold storage for the rest of the war, it cannot be denied that the British also started to look into the process for making the future constitution of India as it was stated in the draft declaration of the Cripps Mission (published $30^{\text {th }}$ March, 1942) that, 'provision shall be made ...for the participation of the Indian states in the constitution making body'. Second, the second important change was appeared in the attitude of Indian leaders. As the Indian leaders were not satisfied with the Cripps proposal, they became more desperate to gain complete independence for India. More clearly, the failure of the Cripps Mission prepared the ground for Congress action against what many Indians now believed to be an imperial war, which they had been unnecessarily dragged into against their wishes[2].

However, a lot of work has already been done on the nature of Cripps Mission. The most notables among them are Ends of British Imperialism: The Scramble for Empire, Suez and Decolonisation by William Roger Louis, New Light on the Cripps Mission (published in India Quarterly, Jan., 1972), Churchill, Cripps and India by R.J.Moore, The Road to 1945 by Paul Addison etc. Almost in every works the situation in which the mission was originated, its nature of work in India, the causes for its failure etc has been shown. But how British 
started the process to give constitutional rights through the launching of Cripps Mission and how indirectly its result brought a new transition in the system of freedom struggle has been almost neglected. Therefore the main purpose of the present article is to highlight that neglected area. At the same time how the long term outcome of Cripps Mission accelerated the process to the way of Indian independence will also be highlighted in this paper.

\subsection{Demands for India's Political Reform:}

\section{Genesis of the Cripps Mission}

From December, 1941 to February, 1942 the significant international events opened a new chapter in the history of India's political reforms. In December, 1941 American president Roosevelt raised the question of Indian political reform in his talks with British Prime minister Churchill in Washington. On $2^{\text {nd }}$ January, 1942 Indian liberal leaders like Sapru and Jayakar appealed for immediate dominion status and also demanded for the expansion of the Viceroys Executive into a national government. In the same month when Chiang-Kai-Shek, the president of the Chinese Republic visit to India, he publicly expressed his sympathy to 'India's aspirations for freedom'. Even some news papers like Times and the Manchester Guardian reflected an expectation that the Government would offer inducements to India to co-operate in the war effort. All these significant matters had set the platform for making a pro-Indian group in Britain. In this Scenario two important groups played a very important role there. One is labour member of the war cabinet like Cripps and Atlee and another is Quaker-dominated India conciliation group under Agatha Harrison. Both of this group favoured the immediate constitutional reform in India. Meanwhile Cripps acquired his personal experience and realised the necessary for some modifications in the Filkinsformula of June, 1938 through his personal visit to India in December, 1939.It has been writing that, "there emerges a picture of a rather loose federation...with the right of provinces to withdraw if they wish -the germ of the provincial option idea which would form the basis of the Cripps plan two years later'[3].

\subsection{War Cabinet and Cripps Mission:}

The Cripps Mission coincided in time with the crisis of the war in South East Asia. Singapore had fallen on 15 February, Rangoon on 8 March, the north eastern provinces of British India was threatened with actual invasion and the whole country was overshamed by the possibility of it. During this period in the hope of creating some common front, proposals had been put forward by certain of the Congress leaders for the recognition of India's sovereign status and for the formation of an all-Indian National Government. These issues were carefully considered by the cabinet, and the usual voluminous correspondence Passed between the India office and the Viceroy. Almost all the members of the war cabinet felt that an offer of dominion status after the war must be made in the most impressive manner to the peoples of India. In a personal telegram on 16 February, 1942, Churchill wrote to the Viceroy that, 'my own idea was to ask the different communities of India-Hindus, Moslems, Sikhs, Untouchables etc. to give us their best and leading men for such a body as has been outlined. However, the electoral basis proposed which was the best we could think of here, may have the effect of throwing the whole council into the hands of the Congress caucus'. [4]

Hence, the diplomatic steps taken by the war cabinet accelerated the launching process of Cripps Mission. On 6 March, 1942, the permanent under secretary of state at the India office, sir David Monteath, in a minute that was circulated to the war cabinet committee by the secretary of state, noted that while the 'insistent demand in India (and in this country) is for complete Indian control or a fuller Indian share in control of India's war effort now', the draft declaration concentrated 'on the future constitution and does not deal at all with the present-except in the last paragraph and then without precision and only in very general terms'. On 9 March, the cabinet accepted the offer of sir Stafford Cripps, who had replaced Atlee as lord Privy Seal, to negotiate on the basis of the draft declaration in India, while the viceroy, on the same day, announced and explained his decision to resign should the declaration be made in the form then before cabinet committee [5]. On 10 March, Churchill explained the considerations which had prompted the Cripps Mission and urged the Viceroy not to resign. However, the instructions actually issued to Cripps by the India committee of the war cabinet were as follows:

"You are authorised to negotiate with the leaders of the principal sections of Indian opinion on the basis of paragraph 1(e) of the 'statement of policy' for the purpose of obtaining their immediate support for some scheme by which they can partake in an advisory or consultative manner in the counsels of their country. You may offer them, if you consider it wise or necessary, positions in the Executive Council, provided this does not embarrass the defence and good government of the country during the present critical time. In relation to this matter you will, no doubt, consult with the viceroy and Commander-in-Chief, and will bear in mind the supreme importance of the military situation".[6] 


\begin{tabular}{|l|l|}
\hline \multicolumn{2}{|c|}{ WAR CABINET (from 19 February, 1942) } \\
\hline Prime Minister and First Lord of the Treasury, Minister of Defence. & Mr. Winston S Churchill \\
\hline Deputy Prime Minister and secretary of state for Dominion of Affairs. & Mr. Clement Atlee \\
\hline Lord Privy Seal and Leader of the House of Commons. & Sir Stafford Cripps \\
\hline Lord President of the Council. & Sir John Anderson \\
\hline Secretary of State for Foreign Affairs. & Mr. Antony Eden \\
\hline Minister of Production. & Mr. Oliver Lyttelton \\
\hline Minister of Labour and National Service. & Mr. Earnest Bevin \\
\hline \multicolumn{2}{|c|}{ INDIA OFFICE } \\
\hline Secretary of State. & Mr. L.S. Amery \\
\hline Permanent Under Secretary. & Sir David Monteath \\
\hline Parliamentary Under-Secretary & Duke of Devonshire \\
\hline Deputy Under-Secretary & Mr. W.D. Croft \\
\hline Assistant Under-Secretaries & Sir Leonard Wakely. Mr. P.J. Patrick \\
\hline Private Secretary to Secretary of State & $\begin{array}{l}\text { Mr. F.F.Turnbull. During his absence with } \\
\text { Sir S. Cripps (from12 March). Mr. M.J. } \\
\text { Clauson }\end{array}$ \\
\hline
\end{tabular}

TABLE-1. List of Principal Holders of War Cabinet and India Office, United Kingdom.

Source: Nicholas Mansergh. (ed), The Transfer of Power 1942-7, vol.1, the Cripps Mission, January-April, 1942(CUP, London, 1970), p.xix, NMML, New Delhi.

\subsection{Arrival of Cripps and the list of invitees}

\section{Cripps in India}

The Lord Privy Seal, Sir Stafford Cripps, provisionally planned to arrive at Karachi by air about 21 or 22 March, accompanied by Francis Turnbull, Private Secretary to Leopold Amery, the Secretary of State for India. Finally Cripps and his party arrived in Delhi on Sunday, 22 March, 1942. On his arrival, Hindus and probably some Congress Muslims of North-West Frontier Province were pleased to think that Cripps was a friend of Nehru's and hoped that practical difficulties would be solved in a way acceptable to Hindus and Congress and, above all, that a Pakistan solution might be avoided[7]. Cripps intention was not to stay longer than about a fortnight unless it transpired that there was a definite Prospect of doing business and on the basis of the war cabinet's policy. However, a list of the Indian leaders with whom Cripps would prefer to talk was prepared and the name of the leaders of the various political parties mentioned in it was as follows:

i. $\quad$ Congress $>$ Gandhi, Azad, Nehru, Rajaji, Pant, Kher, Khan Sahib.

ii. Muslim League> Jinnah, Punjab premier sir Sikandar Hayat Khan, Nazimuddin, Sadullah.

iii. Liberals $>$ Sapru, Jayakar, Setalvad.

iv. Muslim non-League>Bengal Premier FazlulHuq, Sind Premier Allah Bakhsh.

v. Depressed class>Ambedkar, Rajah.

vi. Labour Party> Joshi, Jamnadas Mehta, M.N Roy.

vii. Hindu Mahasabha $>$ Savarkar, S.P Mukherje

viii. Sikhs> One or two recommended by the Punjab Governor.

Along these leaders, representatives from a number of states were also invited. The most notables among them were Nawanagar, Bikaner, Patiala, Bhopal, Kashmir, Orissa, premier Maharaja of Parlakimedi, Dewan of Hyderabad, V.T. Krishnamachari from Baroda, sir C.P. RamaswamyAiyer from Travancore. By seeing such a long list of invitees, legendary congressman MaulanaAbulKalam Azad said that, 'the only reason for inviting all such parties to meet sir Stafford was to use them as 'possible counterweights to' and exert some pressure on Congress despite their lacking and 'strength and courage' to oppose a British settlement with Congress and, further, to inform the outside world that there were many parties in India and 'Congress could not speak for the whole country'.

\subsection{Cripps and his proposals}

Cripps carried with him a draft scheme of the Government for settling the Indian political problem. Through the preamble of the draft resolution it was said that its object was "the creation of a new Indian union which shall constitute a dominion, associated with the United Kingdom and the other dominions by a common allegiance to the crown, but equal to them in every respect, in no way subordinate in any aspect of its domestic or external affairs". Generally the scheme had two parts. The first part dealt with the procedure for formulating the Dominion constitution. This process was to be conducted through three steps. The first step was the holding of fresh elections for all the provincial legislatures. The second step prescribed that the members of the lower houses of the new provincial legislatures together with the representatives of the states were to function as the Electoral College whose business was to elect the constitution making body. It was also laid down that "the strength of this body would be about one-tenth of the total number of the Electoral College, and its members would be elected according to the system of proportional representation". In the third step a very important 
political aspect was raised. On the one hand it seems that constitution making process was accelerated through this proposal but on the other hand it also seems that separation was also put in its optional scheme for the provinces. Because according to the third step the constitution making body would prepare the constitution for the Indian union. But if at the final stage a province expressed its unwillingness through a vote of its legislature to accept the constitution "it was free to refuse accession to the Indian union". It would then proceed to formulate its own constitution which would have the same status, powers and function as the union of India. The draft also proposed that to safeguard the interests of the minorities, treaty would be made between His Majesty's Government and the constitution making body. However, both Linlithgow and Wavell opposed the notion of the right of a province not to accede to the union, but it was the firm belief of the war cabinet that the provincial option was only solution of the communal question.

On the other hand the second part of the scheme was consisted with the immediate and interim arrangements during the period of the war. It recognised that the task of organising the military, moral and material resources of India was the responsibility of the Government of India with the co-operation of the people of India. The Indian leaders, were, therefore invited to the counsels of the country, the commonwealth and the United Nations for active and constructive help. However, the draft declaration was begun with a very important comment. It was said that, 'His Majesty's Government, having considered the anxieties expressed in this country and in India as to the fulfilment of the promises made in regard to the future of India, have decided to lay down in precise and clear terms the steps which they propose shall be taken for the earliest possible realisation of self-government in India. The object is the creation of a new Indian Union which shall constitute a Dominion, associated with the United Kingdom and the other Dominions by a common allegiance to the Crown, but equal to them in every respect, in no way subordinate in any aspect of its domestic or external affairs'.[8]

\section{Reactions, failure and aftermath of the Cripps Mission in Indian perspective 4.1 Contradictions among Indian political parties}

The draft resolution of the Cripps Mission had brought a lot of confusion as well as contradictions among various political parties in India especially between the Congress and the Muslim League. It was not possible for the Congress to accept the proposal wholeheartedly. Infact Gandhiji who met Cripps on March 27 told him bluntly that, "if his offer was no more than what was contained in the draft declaration then he need not stay in India but better take the first plane back to England'. The main objection of the Congress to the Cripps Proposal was that there was not a single time mention of the complete independence for India either in the immediate present or in the future. Besides its other serious objections were the acceptance of Pakistan proposal in the provision and the selection of the state representatives by the rulers. Apart from these the other objectionable matters of the proposal to the Congress Was the question of the status of the Executive council and its defence member. According to Cripps, "His Majesty's Government must keep control of defence, but apart from that participation of others would be welcome to any extent that His Excellency desired". On the other hand, however, it was found that in the list of members of the Executive Council prepared by Cripps, all most all of them were Indians except the Commander-in-Chief and the Viceroy. Therefore, Linlithgow's blunt reaction was, 'that's my affair; Cripps way trying to 'bait the trap with my chese'. Hence from a lot of observations and private conversations of Cripps, the Congress leaders had reached in conclusion that the British authority had no desire to the transform of Executive Council into a national government composed of Indian members-with the exception of the Defence member, in which the Viceroy would have the same position as the king vis-a-vis the British cabinet. 'Independence would be recognised after the war'-this matter disturbed the Congress in such a way that in the resolution of the Congress working committee, it was said that, "any proposal concerning the future of India must demand attention and security, but in today's grave crisis it is the present that counts and even the proposals for the future are important in so far as they affect the present. The committee necessarily attacked the greatest importance to this aspect of the question and on this ultimately depends what advice they should give to those who look to them for guidance". Moreover, Maulana Azad said, "these proposals in effect ask for participation in the tasks of today with a view to ensure the future freedom of India. Freedom was for an uncertain future, not for the present and no indication was given in clause (e) of what arrangements or governmental and other changes would be made in the present". Ultimately, Gandhi rejected the Cripps offer by saying that, it is a post dated cheque on a crushing bank.

On the other hand the Muslim League showed mixed reaction towards the Cripps proposal. Though there was one cause for supporting the proposal by Muslim League as the decision was taken to allow the provinces to opt out of an Indian union; they could, if they wished, stay under the British or achieve independent Dominion Status in their own right, there was no clear mention about the formation of 'Pakistan'. Indeed, it became evident that the proposed solution of Cripps was to give provinces, but not communities, the right to decide whether to come into the Indian union or not; it had the additional merit of showing what the logical consequences of Jinnah's unspecific demand for Pakistan were likely to be, and how feeble the League's grip was over its most important constituents, namely the Muslim-majority provinces. By offering a provincial not a 
communal option Cripps hoped to provide a powerful incentive for those very constituents on whom Jinnah's strategy depended to unhitch their wagons from the League's train[9]."Jinnah could see the pitfalls of the Cripps offer is shown by the way he concentrated on the problem of how local option was to be worked in the Punjab and Bengal (non-Muslim majority provinces), while the Congress leaders, anxious to have an immediate say at the centre, failed to seize the opportunity of using local option to undermine Jinnah. If Congress had accepted it, Jinnah would have been in danger of being dumped unceremoniously but permanently into a wilderness from which this time there would be no return. So he tried to blunt the point of Cripps's thrust by stressing the communal line, and demanding a plebiscite of Muslims alone to decide the question of secession in their majority provinces-self determination for Muslims alone".

\subsection{Cripps's failure}

The opposition of most of the principal political parties in India towards the Cripps proposals led to the failure of the Cripps Mission. Apart from the opposition of India political parties, the British authorities also did not approve the whole work of Cripps in India. Indeed, the actual work of sir Stafford Cripps was not according to the original policy of war cabinet. It has been write that, once Indian began to move towards self-government after the war, it was inconceivable to think of it without the Congress. Congress and the strong centre were the best insurance the British could take out to prevent chaos and balkanisation in India they proposed to leave. But giving Congress the strong centre it wanted was difficult to square with the provincial thesis of the Punjab and Bengal. This was the dilemma that Cripps was trying to resolve. His optional scheme was implemented for the provinces and not communities. Such initiatives, however, was not approved by Viceroy. More over the Viceroy also did not agree with the need of associating an Indian with defence. The request of Cripps, "if some adjustment can be arrived at will you give me full authority subject to agreement of commander-in-chief and Viceroy', was turned down by the war cabinet. Churchill informed Cripps, "I cannot give you any authority to compromise on Defence without submitting issue both to cabinet and Minister above the line". The opposition also came from the Viceroy for a peculiar proposal of Cripps i.e. the transformation of Executive Council into national government. The war cabinet was also stand in favour of Viceroy and rejected Cripps opinion. More clearly the cabinet rejected the suggestion of a convention to restrict the powers of the Viceroy. Thus the uncompromising attitude of both the war cabinet and Indian leaders led to the failure of the Mission. The refusal of the cabinet to support Cripps made him feel humiliated and he came to the conclusion that his further stay in India would not serve any useful purpose. That's why he made up his mind to return. Though he had confusion to decide the matters that on whose part the responsibility for the failure of the Mission lies-Congress or British war cabinet. And not surprisingly, he chooses to blame Congress and its demand for an immediate National Government at the centre. He interpreted Congress's stand as implying a demand for a system of government 'responsible to no legislative or electorate... and the majority of whom would be in a position to dominate large minorities[10].

\subsection{Aftermath of the Cripps Mission: a new turn in India's political field 4.3.1 Break of British policy}

Ultimately Cripps Mission was failed. India did not get her freedom. On the other hand the British policy to draw the India support was also failed. But still the story is not finished. Indeed, today the real interest of the abortive Cripps Mission lies not in the fact that it failed, or even in the reasons why it failed, but in the novel commodity. That is the option for provinces to stay out of an independent Indian union. This was a break with the most sacred principle of British policy-the unity of India. But at the same time it must be said that through this Mission the background of making the Indian constitution was prepared. There is no doubt that Cripps's aim was to reopen the question of India's constitutional future by removing the obstacle which Jinnah's demand for Pakistan had placed in its way. Cripps wanted to achieve this by driving a clear distinction between on the one hand real attachment to provincial autonomy and the fears among provincial leaders of a strong centre once the British left and on the other the vaguer sentiments of communal solidarity. Cripps realised that the politicians of Punjab and Bengal had an outlook of provincial and not communal. "Their first concern was to retain Punjab for the Punjabis, Bengal for the Bengalis and to shut out 'busybodies' from outside. These two provinces had the majority of non-Muslim populations who forced the leaders of these two provinces to realise that they needed to come to terms with other communities".

Except two principle communities of India i.e. Hindus and Muslims, the minorities also gradually became important components in Indian political sectors. From the draft resolution and the proposals of Cripps it can be said that Government relied upon the loyalty of the minorities-the Muslims and the scheduled castes, the co-operation of the princes and the support of the moderates whose detestation of civil-disobedience overcame their dislike of government policy. By offering membership in the executive council, the National Defence Council, the Imperial Defence Council, etc., it was possible to satisfy the demand for the co-operation of Indians in important bodies. 


\subsubsection{Cripps failure and the beginning of intense mass movement}

Cripps failure had made Indian leaders too desperate to gain the independence for India. From this period the nationalist movement of India had acquired a new dimension which finally made the path to independence. That's why it has been right to say that the Cripps offer was the point at which the British departure after the war became inevitable. So "a hasty and ill conceived attempt in large part designed to placate opinion outside India as well as to attract Indian politicians' co-operation at one of the war's darkest hours became the charter for India's freedom[11]. Though during the programmes of Cripps in India, there were such considerations that made even men of the Left in England hesitate about advocating the immediate establishment of a National Government in India in the spring of 1942. They held the view that India had waited so long; could she not wait a few months, a year or two longer, till the Japanese menace had been successfully resisted, till the transfer could be carried through without fear that the inevitable dislocation o a period of transition would be used as an opportunity for a Japanese invasion?[12] The immediate answer of Indian leaders especially the Congress Working Committee was that, 'No, we can wait no longer'. Precisely because they were at the historic moment, Indian leaders feel that at this climax of history they were denied the direction of a great nation's destiny. Not after the war, but now, was the grand moment for proving their worth. As Gandhi expressed, "with them (i.e. the British Government) it seems that to lose India is to lose the battle. It is terrible if it is true. In my opinion to keep India as a possession is to lose the battle".

Thus the summer of 1942 found Gandhi as uniquely militant mood. It has been recognised among historians that "the Cripps proposals were a half way house towards the eventual goal of full freedom to India". Its failure brought about a distinct change in Gandhi's attitude. The failure of the Cripps Mission had determined Gandhi to launch an intense mass movement. He now asked for complete British withdrawal by raising the slogan 'Quit India'. Though from a letter of Gandhi, date 22 ${ }^{\text {nd }}$ April, 1942 to his English friend, Horace Woodbroke it is evident that Gandhi did not want to have anything to do with the Cripps Mission and only went there on the importunities of the working committee members[13]. He seems to have been absolutely opposed to the proposals which had been brought and had said so more than once in the Harijan. Indeed, after the phase of Cripps Mission, Gandhi had set his heart more and more upon complete independence. It was soon afterwards that he put forward his demand for its immediate grant. Nevertheless he felt the failure of the Mission as a further blow to the realisation of India's independence and comments in Harijan like 'that ill-fated proposal' a week before he launched his Quit India Movement is evidence of the despair which then seized him. He regarded the Cripps Mission as unfortunate even in its conception and appeared impressed with the strength of the 'imperial machinery' as opposed to India's weakness. The real purpose, however, became clear to all the Congressmen that through this Cripps card the British wants to create a new psychological approach to the people to make them feel that their own national government had come, that they were defending their newly own freedom. But the Indians became completely frustrated when they saw this old picture again with even the old level on. The continuation of the India office which had been a symbol of evil to Indians confirmed this picture.

So from this phase Indian National Movement became more intense and thus the way of the transfer of power by the British to the Indian hands was accelerated. Gandhi firmly believed that both British and Japanese are the imperialist nations who only want to dominance on the economy and polity of other nations. That's why when the possibility of the Japanese attack on British India was raised; the only solution to save India for Gandhi was the call for British withdrawal from India. He knew very well that India is not the enemy of Japan. But as India is British colony, it became the target of the Japanese. With the coming of Cripps along with the Indian people Gandhi also thought that now a national government might be established in India. "Cripps was a personal friend of Nehru, who was prepared, both on that ground and on Cripps political record, to give his proposals favourable consideration. But he did not like them; they fell far short of his demand; ad he concluded that the British Government, in spite of Cripps, had still not changed its mind".

\subsubsection{By-product of Cripps Mission}

So the Cripps proposal was not totally fruitless. After the war the attraction of political co-operation was still necessary. Cripps basic offers i.e. formation of an elected body for framing a new constitution of India after the cessation of hostilities, establishment of Indian Dominion, giving right to the provinces to make separate constitutions and proposal for a treaty to be signed by the Government and constitution making body of India- all of these were appeared in the constitutional developments of the post Cripps Mission period. Gradually Britain was taking preparations to give more open political and constitutional concessions to India which we can see especially in the offers of Cabinet Mission, 1946. The provincial mater of the Cripps proposal had acquired a new dimension in the Cabinet Mission, 1946 when it was said that, all subjects other than the Union Subjects and all residuary powers should vest in the provinces. Hence, Indian leaders no longer had to be incorporated into the foundations of imperial power. They had to be persuaded to participate in provincial and central government until power could be transferred to legal successors to the British. The politicians including 
Congressmen readily formed provincial governments after the elections of winter 1945-46. The failure of the Cripps Proposal also created a possibility for developing of an international forum of eminent intellectuals. It has been proved that on $12^{\text {th }}$ October, $1942 \mathrm{Mr}$. Bertrand Russell in New York accompanied with Pearl S. Buck, Louis Fisher and T.A Raman after expressing the regret for the failure of the Cripps Mission said that negotiations should be renewed with a view to find some compromise which will be acceptable to the Indian leaders. He also suggested for the setting up of a four-man commission representing United States, Britain, the Soviet Union and China[14]. In course of time, a number of the constitutional development was occurred in India in the forms of Cabinet Mission Plan, the interim Government, September 2, 1946, British Prime Minister Atlee's declaration on British withdrawal, February, 20, 1947, the Mountbatten plan, June 3, 1947 and Finally the Indian Independence Act, 1947.

\section{Conclusion}

Thus it may be conclude that though negatively Cripps Mission was failed but its impact had fell on the period of 1940s, the climax period of India's National Movement which accelerated the power transfer as well as the process of the gain of India's independence. In this mechanism two important factors worked very effectively. One is the first time positive offers of Cripps Mission like the association of Indians with Defence, optional scheme for the provinces, transformation of the Executive Council into National Government etc. and the other is with the failure of the Mission appearance of a radical change in the attitude of India's leaders especially of Gandhi. These two combined factors, however, finally made the easy way to gain independence for India.

\section{References}

[1] W.M. Roger Louis, Ends of British Emperialism-The Scramble for Empire Suez and De-colonization (I.B Tauris and Co Ltd, 6Salem Road, London, 2006), p.387

[2] SekharBandyopadhayay, From Plassey to Partition-A History of Modern India (Orient Blackswan Private Limited, New Delhi, India, 2009), p.412

[3] R.J. Moore, Churchill Cripps and India 1939-45 (Oxford, 1979), p.12

[4] Winston S. Churchill, The Second World War-The Hinge of Fate (Houghton Mifflin Company, 215, Park Avenue South, New York, U.S.A), P.184

[5] Nicholas Mansergh (editor-in-chief), The Transfer of Power 1942-7, vol-1, The Cripps Mission, January-April, 1942(Cambridge University Press, London, 1970), p.xiii

[6] Tara Chand, History of the Freedom Movement in India, vol-IV (publication Division, Ministry of Information and Broadcasting, Government of India, 1972), p.341

[7] Prasanta Kumar Chatterjee, The Cripps Mission-22 March-11 April, 1942(MaulanaAbulKalam Azad Institute Of Asian Studies, Kolkata, 2oo4),p.3

[8] STATEMENT AND DRAFT DECLARATION BY HIS MAJESTYS GOVERNMENT WITH CORRESPONDENCE AND RESOLUTIONS CONNECTED THEREWITH (Sir Stafford Cripps Mission to India), Draft declarations for discussions with Indian leaders, published $30^{\text {th }}$ March, 1942, cited in Cripps Mission, Wikipedia, the free encyclopaedia.

[9] Ayesha Jalal, THE SOLE SPOKESMAN-Jinnah, the Muslim League and the demand for Pakistan (Cambridge University Press, Cambridge, 1994), p.75

[10] Rizvi, Linlithgow and India, p.203

[11] Judith M. Brown, Modern India-The Origins of an Asian Democracy (Oxford University Press, New York, 1984), p.318

[12] Horace Alexander, India Since Cripps (Penguin Books, New York, 1944), p.19

[13] P.N.Chopra, Wickendens Report cited in Quit India Movement: British Secret Report (Thompson Press Limited, Faridabad, India, 1976), p.150

[14] Bijit Kumar Dutta(ed.), Quit India Movement as reported in newspaper and periodical(Poschimbanga Bangla Academy, Kolkata, India, 2004), p.391 